\title{
PERFORMANCE OF HOLSTEIN COWS FED SUGARCANE OR CORN SILAGES OF DIFFERENT GRAIN TEXTURES
}

\author{
Clóvis Eduardo Sidnei Corrêa ${ }^{1}$; Marcos Neves Pereira ${ }^{2 *}$; Simone Gisele de Oliveira ${ }^{3}$; Marcelo \\ Hentz Ramos ${ }^{4}$ \\ ${ }^{1}$ Rehagro - 35710-000 - Inhaúma, $M G$ - Brasil. \\ ${ }^{2}$ UFLA - Depto. de Zootecnia, C.P. 37 - 37200-000 - Lavras, MG - Brasil. \\ ${ }^{3}$ USP/ESALQ - Depto. de Produção Animal, C.P. 9 - 3418-900 - Piracicaba, SP - Brasil. \\ ${ }^{4}$ Undergraduate Veterinary Medicine Student - UFLA. \\ *Corresponding author <mpereira@ufla.br>
}

\begin{abstract}
Corn cultivated in Brazil is predominantly of hard texture, and more propense to decreased starch digestibility under late harvesting situations than dent hybrids. This work tested the utilization of dent corn as a way of extending the ensilage period without reducing animal performance, and evaluated the potential of sugarcane as a forage for high-producing dairy cows. Nine lactating Holstein cows were allocated to three $3 \times 3$ latin squares and were fed $200 \mathrm{~g}$ of forage neutral detergent fiber per kg of dry matter as either hard texture corn ensiled at the half milk line stage of maturity, soft texture corn ensiled at the black layer stage, or sugarcane. There were no detectable differences between corn hybrids with regard to milk yield $\left(34.2 \mathrm{vs} 34.6 \mathrm{~kg} \mathrm{~d}^{-1}\right)$ and composition, dry matter intake ( $\left.23.0 \mathrm{vs} 23.2 \mathrm{~kg} \mathrm{~d}^{-1}\right)$ and total tract apparent digestibility of nutrients. Sugarcane decreased feed intake $\left(21.5 \mathrm{~kg} \mathrm{~d}^{-1}\right)$ and milk yield $\left(31.9 \mathrm{~kg} \mathrm{~d}^{-1}\right)$. Organic matter digestibility, chewing activity and rumen $\mathrm{pH}$ did not differ among treatments. Sugarcane seems to be a viable option to feed groups of Holstein cows during lactation stages in which nutrient demand is not at a maximum. The performance of dairy cows fed dent corn ensiled at the black layer stage of maturity was similar to the performance of cows fed flint corn ensiled at the half milk line stage.
\end{abstract}

Key words: flint corn, dent corn, digestibility, stage of maturity

\section{DESEMPENHO DE VACAS HOLANDESAS ALIMENTADAS COM CANA-DE-AÇÚCAR OU SILAGENS DE MILHO DE DIFERENTES TEXTURA DE GRÃO}

\begin{abstract}
RESUMO: O milho cultivado no Brasil é predominantemente de textura dura, e mais propenso a redução na digestibilidade do amido em situação de colheita tardia que híbridos dentados. Este trabalho testou a utilização de milho dentado como maneira de ampliar o período de ensilagem sem reduzir o desempenho animal e avaliou o potencial da cana-de-açúcar em dietas para vacas leiteiras de alta produção. Nove vacas Holandesas foram alocadas em três quadrados latinos $3 \times 3$ e alimentadas com $200 \mathrm{~g}$ de fibra em detergente neutro oriunda de forragem por $\mathrm{kg}$ de matéria seca como milho de textura dura ensilado no estádio de maturação "metade da linha do leite", milho de textura macia no estádio "linha negra" ou cana-de-açúcar. Não foi detectada diferença entre híbridos de milho na produção ( 34,2 vs $\left.34,6 \mathrm{~kg} \mathrm{~d}^{-1}\right)$ e na composição do leite, no consumo de matéria seca $\left(23,0 \mathrm{vs} 23,2 \mathrm{~kg} \mathrm{~d}^{-1}\right)$ e na digestibilidade aparente de nutrientes no trato digestivo total. A cana-de-açúcar deprimiu o consumo $\left(21,5 \mathrm{~kg} \mathrm{~d}^{-1}\right)$ e a produção de leite $\left(31,9 \mathrm{~kg} \mathrm{~d}^{-1}\right)$. A digestibilidade da matéria orgânica, a atividade mastigatória e o $\mathrm{pH}$ ruminal não foram diferentes entre tratamentos. A canade-açúcar parece ser uma opção para alimentar grupos de vacas Holandesas durante fases da lactação na qual a demanda nutricional não é a máxima. O desempenho de vacas leiteiras alimentadas com milho dentado ensilado em estádio de maturação "linha negra" foi similar ao de vacas alimentadas com milho duro ensilado no estádio "metade da linha do leite".

Palavras-chave: milho duro, milho dentado, digestibilidade, estádio de maturação
\end{abstract}

\section{INTRODUCTION}

Forages with low fibrous carbohydrate content, which undergo slow degradation in the rumen, and a high proportion of non-fibrous carbohydrates, such as starch and sucrose, make possible the production of milk with low grain input per yielded liter, because of their high energy value. Corn silage and sugarcane are forages that characteristically present high dry matter yield per unit area and high energy value, allowing high animal stocking rates on diets formulated with high forage to concentrate ratio. Corn silage has been the predominant forage in Brazilian farms working with high-yielding dairy animals. The high sucrose accumulating capacity of sugar- 
cane has been explored by the sugar and alcohol industry, ensuring high technological level of this crop in Brazil, as well as yield potential per area greater than that of corn. The possibility of totally or partially replacing corn silage by sugarcane can increase efficiency in farms that raise high-yielding dairy cattle.

Sugarcane has been recommended for dairy farms that utilize low-yielding cows, submitted to feeding regimes that do not seek to obtain high lactating performance per animal (Preston \& Leng, 1980). In diets consisting of sugarcane and urea only, factors associated with the formulation, and not exclusively to the sugarcane, may explain the low intake and lack of ability to maintain positive energy balance in non-lactating and nonpregnant cows (Sucupira, 1998; Stacchini, 1998). The utilization of sugarcane and other feedstuffs, should be based on dietary formulations that incorporate nutritionalmodel recommendations of practical use (NRC, 2001). Daily weight gains around $1 \mathrm{~kg}$ were obtained when sugarcane was utilized in dietary formulations for Holstein heifers, in spite of the fact that it was limiting to performance, comparatively to corn silage (Andrade \& Pereira, 1999). Sugarcane was also considered adequate for dairy cattle producing $20 \mathrm{~kg}$ of milk per day, in diets formulated with about $50 \%$ of the dry matter from concentrate feedstuffs (Mendonça et al., 2001). The sugarcane yield support potential, in balanced diets, must be defined more precisely to allow recommendations to be specifically targeted. No scientific data exist to support the use of sugarcane in diets formulated for high-performance lactating animals.

Corn can be classified with reference to grain texture as dent or flint. Dent grain have low density and consist of soft and porous starch. Flint grain have a hard or crystalline endosperm occupying almost the entire volume of the grain, and possess a low proportion of farinaceous endosperm (Fornasieri Filho, 1992). Vitreousness is defined as the proportion of hard (vitreous) endosperm in relation to the total endosperm. Flint grain have high vitreousness and density. In the United States corn producing region, almost all cultivated corn has dent grain (Coors et al., 1994), while the corn cultivated in Brazil is predominantly flint. There is evidence that the greater the grain vitreousness the lowest the ruminal starch degradability (Corrêa et al., 2002; Philippeau \& MichaletDoreau, 1997; Philippeau et al., 1999). It is therefore important understanding the effect of corn grain texture on performance of dairy cows fed silages made with Brazilian cultivars.

Calestine et al. (2001) observed that the ruminal degradation of grain dry matter of two flint and two dent hybrids available in the Brazilian market decreased as the maturation stage progressed $(P<0.001$ for the quadratic effect of maturation stage). A marked decrease in ruminal degradability occurred when the hybrid went from the half milk line to the black layer stage. The negative effect of corn maturity on ruminal degradability was more striking on flint and more vitreous (67.1 vs $44.3 \%$ of the endosperm) hybrids $(P<0.001$ for the interaction between texture and maturation stage). It seems that the utilization of dent hybrids, as compared to flint hybrids, may result in smaller decrease of starch digestion in the rumen when harvest time is delayed.

Since corn ensiling in Brazil takes place during the rainy season, this practice is subject to operational failures that many times result in the harvest being unintentionally delayed past the plant's more suitable stage. Since the relative decrease in rumen degradability was smaller in dent than in flint grain as maturation progressed (Calestine et al., 2001), the hypothesis that the utilization of dent corn would be a way of lengthening the harvest period for silage corn without reducing animal performance was tested. The objective of this work was to evaluate milk yield of Holstein cows fed sugarcane and dent or flint corn silages.

\section{MATERIAL AND METHODS}

Nine Holstein cows, 6 multiparous and 3 primiparous, with $123 \pm 33$ days of lactation (mean \pm standard deviation) in the beginning of the experimental period, were individually fed in a tie-stall barn with sand bedding and continuous access to water, at Ijaci, MG, Brazil (2110'12"S; 4455'31'W). The multiparous animals were allocated into two groups of three cows, based on their milk yield immediately prior to the beginning of the experimental period, and randomly allocated to one of three possible treatment sequences in two $3 \times 3$ Latin Squares, with 21-day periods. A third square consisted of the primiparous cows. The three squares received the treatments at the same time. The three treatments were: Soft or dent corn silage (Agroceres 4051) harvested at the black layer stage (MM); flint corn silage (Pioneer 3041) harvested at the half milk line stage (MD); or sugarcane (variety RB 72454) (CA) (Table 1). The three forage options were utilized as the only dietary forage in diets formulated to contain the same percentage of forage neutral detergent fiber (NDF) and protein (Table 2).

Corn hybrids were chosen to represent extremes of endosperm texture available in the Brazilian corn seed market. The Pioneer 3041 hybrid was one of the most dense and the Agroceres 1051 hybrid was the least dense among 103 hybrids evaluated by Guimarães (1997). The correlation between density and endosperm vitreousness is high and positive (Corrêa et al., 2002). Calestine et al. (2001) evaluated the texture of hybrids Agroceres 1051 and 4051, and concluded that grain vitreousness in these hybrids is similar to the vitreousness of NorthAmerican dent hybrids (Corrêa et al., 2002). 
Table 1 - Nutrient composition of dent corn silage ensiled at the black layer stage, of flint corn silage ensiled at the half milk line stage and of sugarcane.

\begin{tabular}{|c|c|c|c|}
\hline & \multicolumn{2}{|c|}{ Corn silages } & \multirow{2}{*}{ Sugarcane } \\
\hline & Dent & Flint & \\
\hline & \multicolumn{3}{|c|}{$\%$ of As Fed } \\
\hline \multirow[t]{2}{*}{ Dry matter } & 41.7 & 31.7 & 33.0 \\
\hline & \multicolumn{3}{|c|}{$\%$ of Dry Matter } \\
\hline Organic matter & 97.1 & 96.2 & 98.3 \\
\hline Crude protein & 7.7 & 7.0 & 3.0 \\
\hline Neutral detergent fiber & 44.0 & 42.9 & 43.2 \\
\hline Starch plus free glucose & 29.6 & 33.2 & 5.5 \\
\hline
\end{tabular}

Table 2 - Ingredient composition of the offered diets and nutrient composition of the consumed diets in treatments with dent corn silage ensiled at the black layer stage (DC), flint corn silage ensiled at the half milk line stage (FC) or sugarcane (SC).

\begin{tabular}{|c|c|c|c|}
\hline & $\mathrm{DC}$ & $\mathrm{FC}$ & $\mathrm{SC}$ \\
\hline & \multicolumn{3}{|c|}{$\%$ of Dry Matter } \\
\hline Dent corn silage & 45.8 & & \\
\hline Flint corn silage & & 45.8 & \\
\hline Fresh sugarcane & & & 45.3 \\
\hline Ground dry shelled corn & 28.4 & 28.4 & 25.0 \\
\hline Corn gluten meal & & & 3.9 \\
\hline Soybean meal & 20.5 & 20.5 & 20.5 \\
\hline Meat and bone meal & 1.4 & 1.4 & 1.4 \\
\hline Blood meal & 1.4 & 1.4 & 1.4 \\
\hline Limestone & 0.7 & 0.7 & 0.7 \\
\hline Sodium bicarbonate & 1.1 & 1.1 & 1.1 \\
\hline $\mathrm{NaCl}$ & 0.3 & 0.3 & 0.3 \\
\hline Dicalcium phosphate & 0.2 & 0.2 & 0.2 \\
\hline \multirow[t]{2}{*}{ Vitamin-mineral premix ${ }^{1}$} & 0.2 & 0.2 & 0.2 \\
\hline & \multicolumn{3}{|c|}{$\%$ of As Fed } \\
\hline \multirow[t]{2}{*}{$\mathrm{DM}^{2}$} & 58.1 & 49.0 & 51.0 \\
\hline & \multicolumn{3}{|c|}{$\%$ of Dry Matter } \\
\hline $\mathrm{CP}^{2}$ & 19.6 & 19.1 & 19.6 \\
\hline $\mathrm{NDF}^{2}$ & 26.9 & 27.9 & 27.0 \\
\hline Forage NDF & 20.1 & 19.9 & 19.6 \\
\hline Starch plus Free Glucose & 35.1 & 36.7 & 21.7 \\
\hline Ash & 3.7 & 4.2 & 3.1 \\
\hline $\mathrm{NFC}+\mathrm{EE}$ & 49.8 & 48.9 & 50.3 \\
\hline
\end{tabular}

${ }^{1}$ Vitamin-mineral premix $\left(\mathrm{kg}^{-1}\right)=\mathrm{Co}: 125 \mathrm{mg}, \mathrm{Cu}: 5,625 \mathrm{mg}, \mathrm{Fe}$ : 6,250 mg, I: $312 \mathrm{mg}$, Mn: 18,125 mg, Se: $144 \mathrm{mg}, \mathrm{Zn}: 23,750 \mathrm{mg}$, vitamin A: 2,000 KIU, vitamin D: $500 \mathrm{KIU}$, vitamin E: 12,500 KIU.

${ }^{2} \mathrm{DM}=$ Dry matter. $\mathrm{CP}=$ Crude Protein. $\mathrm{NDF}=$ Neutral detergent fiber. $\mathrm{NFC}+\mathrm{EE}=$ non-fiber carbohydrates + ether extract.
Silages were stored in two bunker-type, 15-t silos with mouth opening dimensioned to allow daily removal of $20 \mathrm{~cm}$ slices, enough to feed the cows receiving each treatment. The sugarcane was harvested daily and chopped twice a day in a stationary chopper, without the removal of leaves.

The ingredients in the diets (Table 2) were weighed by hand, mixed and offered to the animals as a complete diet supplied twice a day, at $7 \mathrm{~h} 00$ and $16 \mathrm{~h} 00$, at an amount sufficient to supply at least $10 \%$ of the offered as refusals. The proportion of ingredients in diet dry matter was kept constant by weekly monitoring forages dry matter content with a Koster-type dehydration apparatus (Koster Crop Tester, Strongsville, OH, USA). Corn gluten meal was utilized in the sugarcane treatment to raise dietary protein to a similar content to those found in diets containing corn silage, while keeping protein quality as similar as possible, since the same amount of protein from soybean meal, and from blood and meat-andbone meals, was maintained. The corn hybrid utilized ground in the concentrates was not identified, but as the same concentrate mix was utilized in all treatments, the effect of the texture of the corn in the concentrate was not a factor of variation in the results.

The weight of orts was determined twice a day throughout the experiment. The daily feed intake was calculated as the amount of feed offered minus the weight of orts. Orts were sampled and frozen on days 15 through 20 of each period and a composite sample was formed for each cow per period by the union of equal amounts of fresh matter from each sample. Samples of silages, sugarcane and concentrates were collected on same days. Forage samples were frozen immediately after sampling and concentrates were stored at room temperature for later formation of a composite sample of each feed per experimental period. Dry matter intake was calculated multiplying the daily intake of each feed between days 15 and 20 of each period by their dry matter content followed by subtraction of the daily amount of orts dry matter from that number.

Cows were weighed on the $21^{\text {st }}$ day of each period. Milking was performed daily at $2 \mathrm{~h} 00,10 \mathrm{~h} 00$ and $18 \mathrm{~h} 00$, throughout the experiment. Milk production was measured on days 18, 19 and 20 of each period, and an 80-mL sample from each milking was collected. To each sample, $2 \mathrm{~mL}$ of bronopol preservative (DF Control System, Dublin, CA, USA) were added. Samples were stored at $5^{\circ} \mathrm{C}$. By the end of the ninth milking, samples were immediately analysed for protein and fat by infrared spectroscopy (Bentley Instruments, Chaska, MN, USA).

From day 10 to 19 of each period, all animals received capsules containing $5 \mathrm{~g}$ of chromium oxide (Sulfal Química, Belo Horizonte, MG) twice a day, to estimate fecal excretion and to determine the total tract apparent digestibility of nutrients. Feces were collected between 
days 16 and 19 of each period, by direct sampling from the rectum of each animal. Fecal sampling was performed at 4-hour intervals. Sampling time was delayed by 1 hour each day; therefore, by the end of the fourth day, one sample was obtained from each hour of the day. A composite sample of feces from each cow in each period was formed by isovolumetric union of each fecal sample. Composite samples were maintained at $-20^{\circ} \mathrm{C}$ until analytical procedures were performed.

Composite samples of feeds, orts and feces were dehydrated in a forced ventilation oven for 72 hours at $58^{\circ} \mathrm{C}$ and ground through a $1 \mathrm{~mm}$ sieve with a Wiley-type mill. A sub-sample was incubated at $105^{\circ} \mathrm{C}$ for 24 hours to determine the dry matter content. Crude protein was determined with a micro Kjeldahl steam distillation apparatus (AOAC, 1975). The ash content was determined by incineration at $550^{\circ} \mathrm{C}$ for 8 hours. The NDF content was determined non-sequentially according to Van Soest et al. (1991). The NDF technique utilized $0.5 \mathrm{~g}$ of sodium sulfite and $200 \mu \mathrm{L}$ of heat stable a-amylase; $100 \mu \mathrm{L}$ added to the beaker while the sample was boiling in neutral detergent solution and $100 \mu \mathrm{L}$ added when the sample was being filtered in a crucible containing hot water.

Starch content was determined by enzymatic degradation of the samples with amylase (Sigma A3306) and amyloglucosidase (Sigma, A3514) (Bal et al., 2000). The technique measures glucose concentration after enzymatic digestion of the starch. If samples contain free glucose before enzymatic digestion, it is detected and its presence might be interpreted as starch digestion residue. This is why results of this analysis were expressed as starch+free glucose. The nutrient composition of the consumed diet (Table 2) was calculated from the composition of the feeds, their proportion in the offered dry matter and the amount offered to each cow in each period followed by subtraction of the nutrients contained in the orts per animal. The consumed nutrients were then divided by the total dry matter intake per treatment.

Fecal excretion was estimated from the fecal chromium concentration (Williams et al., 1962). One gram of the pre-dried fecal sample was incinerated at $550^{\circ} \mathrm{C}$ for 8 hours and submitted to digestion in a solution formulated with $1,000 \mathrm{~mL}$ phosphoric acid (85\%), $30 \mathrm{~mL}$ manganese sulfate $(10 \%)$ and $4 \mathrm{~mL}$ potassium bromate $(4.5 \%)$ in a sand bath until effervescence stopped. The material was then transferred to another container where $25 \mathrm{~mL}$ calcium chloride was added (4,000 ppm) and the volume was completed to $100 \mathrm{~mL}$ with distilled water. This solution was filtered through filter paper (Whatman 40) for later analysis of the solution by atomic absorption spectrophotometry (Varian AA-100). Total tract apparent digestibility was calculated for dry matter (DDM), NDF (DNDF), starch+free glucose (DSGL), organic matter (DOM) and non-NDF organic matter (DNNDFOM). The digestible organic matter intake (DOMI) was calculated multiplying the DOM estimated between days 16 and 19 of each period by the organic matter intake $(\mathrm{OM})$ determined between days 15 and 20 .

Chewing activity was determined on day 20 of each period by visual observation of the mouth activity of each animal every 5 minutes for 24 hours uninterruptedly. Mouth activities considered were feed ingestion, water ingestion, rumination and idling. Chewing time in minutes per day was defined as the sum of feed ingestion and rumination times. The chewing, ingestion and rumination times per unit of dry matter intake were determined based on the daily dry matter intake determined between days 15 and 20 .

Rumen fluid samples were obtained on day 21 of each period for $\mathrm{pH}$ determination. Sampling took place ten hours after the morning feeding and animals remained with normal access to feed during the period that preceded collection. Rumen fluid sampling was performed by percutaneous needle aspiration of the ventral sac (rumenocentesis) (Garret et al., 1999). Animals were randomly sampled within square. Rumen $\mathrm{pH}$ was determined immediately after sampling with a portable $\mathrm{pH}$ meter (CG 837 pH-Meter, Schott Gerãnte).

\section{Statistical Analyses}

Variables were analyzed with the GLM procedure of the SAS (1985) statistical package, with the following model:

$$
\mathrm{Y}_{\mathrm{ijk} \mathrm{l}}=\mu+\mathrm{Q}_{\mathrm{i}}+\mathrm{V}(\mathrm{Q})_{\mathrm{j}(\mathrm{i})}+\mathrm{P}_{\mathrm{k}}+\mathrm{F}_{1}+\varepsilon_{\mathrm{ijk} \mathrm{l}}
$$

where: $\mu=$ overall mean, $Q_{i}=$ square effect ( $i=1$ to 3 ), $\mathrm{V}(\mathrm{Q})_{\mathrm{j}(\mathrm{i})}=$ cow within square effect $(\mathrm{j}=1$ to 9$), \mathrm{P}_{\mathrm{k}}=$ period effect $(\mathrm{k}=1$ to 3$), \mathrm{F}_{1}=$ forage effect $(\mathrm{l}=\mathrm{MM}, \mathrm{MD}$, $\mathrm{FC}), \varepsilon_{\mathrm{ijk}}=$ residual error, assumed independently and identically distributed in a normal distribution with mean zero and variance $\sigma^{2}$.

Two orthogonal contrasts with 1 degree of freedom were tested: $(\mathrm{MM}+\mathrm{MD})$ versus $\mathrm{CA}$, for the difference between corn silage and sugarcane, and MM versus MD to test the hybrid texture effect in the corn silage. Non-linear regressions of dry matter intake over day of experimental period were performed for all treatments.

\section{RESULTS AND DISCUSSION}

Corn silages fed in this experiment can be considered of high-quality (Table 1). Fonseca et al. (2002) evaluated the silage of 60 corn hybrids grown in the south of Minas Gerais and found a mean NDF value of $54.5 \%$; the best hybrid in this study had a $44.5 \%$ NDF value. The silages of this study can also be considered as having good quality as compared to international data 
(Bal et al., 1997; Oba \& Allen, 1999; Clark \& Armentano, 1999). The possibility of making high-quality corn silage in Brazil thus becomes clear, as long as plants are submitted to adequate agronomic practices, and adequate hybrids and harvest times are selected. The dry matter content of the dent corn silage (Table 1) characterizes a plant ensiled at a late stage of maturity (Bal et al., 1997). Judging by the percentage of fiber and starch, it seems that the participation of grain in the two silages was similar.

The sugarcane had NDF content similar to the corn silages (Table 1). Sugarcane is characterized by its high content of fast-degrading carbohydrates, with predominance of sucrose, which allows dietary formulations containing small proportion of concentrate feedstuffs (Table 2). Using sugarcane is a way of conciliating high milk yield per hectare with low use of concentrate feedstuffs per unit milk produced. Since sugarcane had a lower protein content than the corn silages (Table 1), the need for protein sources to formulate iso-nitrogenous diets was greater in this diet (Table 2). Since the cost of protein per unit of nutrient is usually high, diets formulated with sugarcane are not necessarily formulations with a low cost per kg of dry matter. Whether or not to use sugarcane, may depend more on agronomic factors and on factors associated to milk yield per unit area than on financial factors.

The total NDF content and the percentage of forage NDF were similar in the consumed diets (Table 2), providing support for the possibility of formulating chemically similar diets by completely replacing dry matter from corn silage by sugarcane. However, the carbohydrate profile in the diet changes completely when sugarcane replaces corn silage. The inferences in this work are limited to diets in which corn silage NDF is replaced by sugarcane NDF, and silage starch is replaced by sucrose. In the diet containing sugarcane, $88.5 \%$ of the starch+free glucose came from corn in the concentrate, while in those containing corn silage, the starch in the concentrate represented about $60 \%$ of the total starch.

Sugarcane depressed dry matter intake (Table 3 ). The dry matter intake as a percentage of live weight was 3.76 for diets containing silage and 3.48 for the diet containing sugarcane, which is representative of high-producing lactating cows (Pereira et al., 1999), and was higher than reported values for lactating cows consuming diets with sugarcane as the only forage (Mendonça et al., 2001). The depressive effect of sugarcane on intake has been widely reported in the literature (Preston \& Leng, 1980; Andrade \& Pereira, 1999; Ribeiro et al., 2000) and occurred in the present study (Table 3), even for diets heavily supplemented with concentrate (Table 2) and with the utilization of good-nutritional-value sugarcane (Table 1).

One possible reason for the low intake of diets with sugarcane would be the frequent supplementation of this forage with urea, which is a low-palatability ingredient (Huber \& Kung Jr., 1981). Sucupira (1998) observed a linear decrease in dry matter intake of non-lactating cows when sugarcane-based diets, containing the same forage NDF content, were supplemented with increasing levels of urea. However, the diets utilized in this work were not supplemented with urea (Table 2). The daily intake of dry matter between days 2 and 7 of each period was $22.6 \mathrm{~kg}$ for diets containing corn silage, and $22.7 \mathrm{~kg}$ for the diet containing sugarcane (Figure 1), apparently indicating that the depressive effect of sugarcane on intake was not a result of diet palatability.

Table 3 - Body weight, dry matter intake (DMI), digestible organic matter intake (DOMI), milk yield and composition in diets formulated with dent corn silage ensiled at the black layer stage (DC), flint corn silage ensiled at the half milk line stage (FC) or sugarcane (SC).

\begin{tabular}{|c|c|c|c|c|c|c|c|}
\hline & $\mathrm{DC}$ & FC & SC & SEM $^{1}$ & $P$ for forage & $(\mathrm{DC}+\mathrm{FC})$ vs $\mathrm{SC}^{2}$ & $\mathrm{DC}$ vs $\mathrm{FC}^{2}$ \\
\hline & $-\cdots$ & $-\cdots$ & $-\cdots$ & $\cdots-\cdots$ & (n- & 烈 & - \\
\hline \multirow[t]{2}{*}{ Body weight } & 613 & 616 & 618 & 3.9 & 0.71 & 0.48 & 0.69 \\
\hline & $-\cdots-\cdots$ & $\ldots$ & 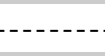 & (n-.... & $\mathrm{l}^{-1}-\ldots \ldots \ldots$ & - & - \\
\hline DMI & 23.0 & 23.2 & 21.5 & 0.6 & 0.13 & 0.05 & 0.82 \\
\hline DOMI & 15.2 & 14.6 & 13.4 & 0.6 & 0.14 & 0.06 & 0.51 \\
\hline Milk yield & 34.2 & 34.6 & 31.9 & 0.4 & $<0.001$ & $<0.001$ & 0.82 \\
\hline Fat yield & 1.20 & 1.22 & 1.16 & 0.02 & 0.13 & 0.06 & 0.46 \\
\hline \multirow[t]{2}{*}{ Protein yield } & 1.06 & 1.08 & 1.02 & 0.02 & 0.11 & 0.05 & 0.41 \\
\hline & --- & & & & & & \\
\hline Fat content & 3.54 & 3.57 & 3.64 & 0.06 & 0.44 & 0.22 & 0.73 \\
\hline Protein content & 3.10 & 3.13 & 3.22 & 0.04 & 0.06 & 0.02 & 0.61 \\
\hline
\end{tabular}

${ }^{1} \mathrm{SEM}=$ Standard error of the mean.

${ }^{2}$ Contrasts: $(\mathrm{DC}+\mathrm{FC})$ versus $\mathrm{SC}$ and $\mathrm{DC}$ versus FC. 
Table 4 - Total tract apparent digestibility of dry matter (DDM), NDF (DNDF), starch plus free glucose (DSGL), organic matter (DOM) and non-NDF organic matter (DNNDFOM) of diets formulated with dent corn silage ensiled at the black layer stage (DC), flint corn silage ensiled at the half milk line stage (FC) or sugarcane (SC).

\begin{tabular}{lccccccc}
\hline & DC & FC & SC & SEM $^{1}$ & $P$ for forage & (DC+FC) vs SC & DC vs FC $^{2}$ \\
\hline DDM & 63.6 & 63.0 & 61.4 & 2.0 & 0.71 & 0.43 & 0.83 \\
DNDF & 42.4 & 41.7 & 23.1 & 3.5 & 0.002 & $<0.001$ & 0.89 \\
DSGL & 89.7 & 91.7 & 95.5 & 1.6 & 0.06 & 0.03 & 0.37 \\
DOM & 65.7 & 65.3 & 63.9 & 2.0 & 0.80 & 0.52 & 0.89 \\
DNNDFOM & 74.5 & 75.0 & 79.8 & 1.6 & 0.06 & 0.02 & 0.84 \\
\hline
\end{tabular}

${ }^{1} \mathrm{SEM}=$ Standard error of the mean.

${ }^{2}$ Contrasts: (DC+FC) versus SC and DC versus FC.

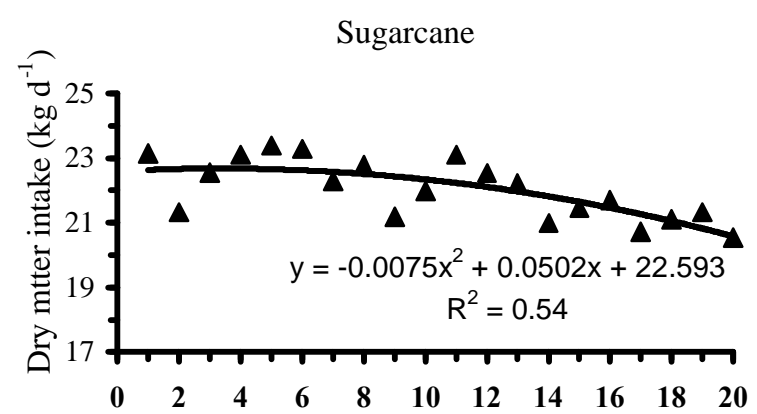

a) Day of experimental period

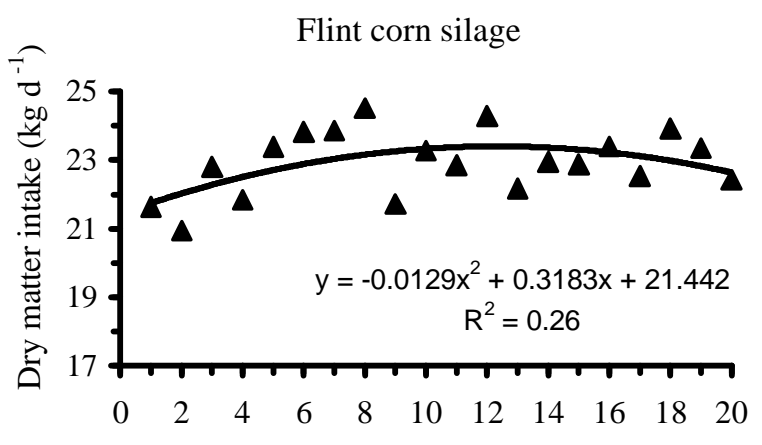

b) Day of experimental period

Dent corn silage

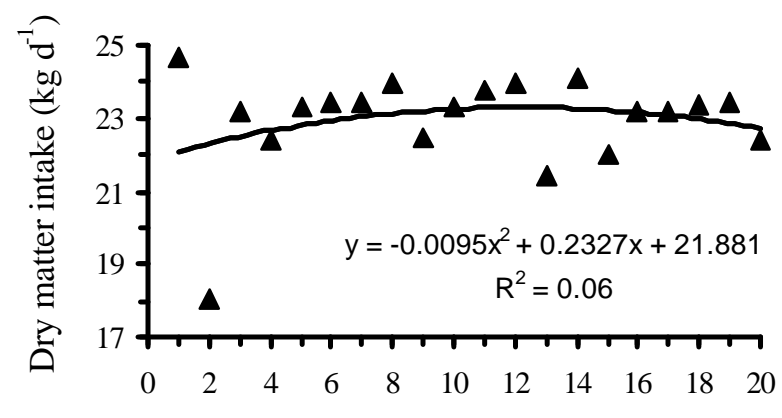

c) Day of experimental period

Figure 1 - Dry matter intake of 9 Holstein cows during the first 20 days of each experimental period in diets containing (a) sugarcane; (b) flint corn silage ensiled at the half milk line stage; or (c) dent corn silage ensiled at the black layer stage, as the only forages.
Low fiber digestibility can promote a reduction in dry matter intake of lactating cows (Allen, 2000). The low fiber digestibility (Table 4) could be a possible cause of the intake reduction induced by diets containing sugarcane. The intake of the diet containing sugarcane over experimental days had a quadratic behavior (Figure 1). Intake was practically constant at the beginning of each period, with a tendency to decrease as days elapsed. This behavior supports the likelihood that as the digestive tract filled as days went by, the intake of diets containing sugarcane was reduced. Since the intake of the sugarcane-containing diet still had a decreasing tendency at the end of the period, a longer experimental period could emphasize differences between forages. Experiments with a continuous design would elucidate whether the depressive effect of sugarcane on dry matter intake are stressed in the long run.

The daily milk yield was $2.5 \mathrm{~kg}$ lower for the sugarcane treatment (Table 3). The lower milk yield of this treatment could have been caused by the lower intake (Table 3), since the lower DNDF of this treatment was compensated by a greater DNNDFOM (Table 4). The DOMI was smaller for the sugarcane treatment than for corn silage treatments (Table 3). Data apparently reflect the limited starch digestibility of Brazilian corn grain. Replacing silage starch with sugarcane sucrose resulted in a 5 percentage units increase in NNDFOM digestibility (Table 4). The greatest nutritional limitation of sugarcane is its low fiber digestibility (Preston \& Leng, 1980). Understanding intake depression of diets containing sugarcane should be a priority in studies with this forage. Sugarcane does not seem to be a good forage option for groups of Holstein cows around stages of maximum nutrient demand in a given lactation. However, daily milk production around $30 \mathrm{~kg}$ seems to be attainable in diets containing sugarcane as the only forage.

Milk protein yield was lower for sugarcane diets than for diets with corn silage (Table 3). Even though diets had similar protein content (Table 2), the daily crude protein intake was $4.22 \mathrm{~kg}$ for sugarcane diets, while intake for corn silage diets was $4.46 \mathrm{~kg}$. This difference in 
protein intake was a consequence of the smaller dry matter intake and could have resulted in lower metabolizable protein absorption for the sugarcane treatment (NRC, 2001). The smaller milk protein percentage of silage treatments probably occurred because of dilution by the higher yield (Table 3 ). Judging by the milk protein yield, the delay in corn ensiling time was not sufficient to affect the availability of dietary starch in the rumen and the synthesis of microbial protein (Table 3).

In diets formulated with $45 \%$ forage (Table 2), the delay in ensiling time for dent corn did not reduce milk yield as compared to flint corn, which was ensiled at an earlier maturity stage (Table 3). The digestibility of dietary starch was not reduced by the delay in corn ensiling time (Table 4). No difference in DOMI was detected between treatments containing dent corn and flint corn (Table 3). The soft texture hybrid ensiled at a late maturity stage did not reduce energy intake and milk yield as compared to flint corn ensiled at the appropriate time.

The sugarcane contained 5.5\% starch+free glucose (Table 1) and the sugarcane treatment contained $45.3 \%$ of this forage (Table 2). Therefore, of the $21.7 \%$ of starch+free glucose in this diet (Table 2), $11.5 \%$ came from sugarcane and $88.5 \%$ came from the concentrate. Assuming that the digestibility of the starch+free glucose in sugarcane was $100 \%$, starch digestibility in the concentrate should be around $94.9 \%$ for this treatment, to have a total starch+free glucose digestibility value of 95.5\% (Table 4). Admiting that the digestibility of the starch in the concentrate was the same in all treatments, it can be estimated that starch digestibility of the dent corn silage was close to $80.7 \%$ and of the flint corn silage was $87.5 \%$. In these formulations, where $40 \%$ of the dietary starch came from corn silage (Tables 1 and 2), possible differences in total tract starch digestibility was not reflected on lactation performance (Table 3).

Calestine et al. (2001) observed that the in situ ruminal degradability of the grain from soft corn hybrids harvested at the black layer stage of maturity was 2.2 times greater than the degradability of flint hybrids harvested at the same stage. However, in the same study, the degradability of soft hybrids harvested at the black layer stage was 35\% lower than the degradability of flint hybrids harvested at the half milk line stage. The estimated difference in starch digestibility between silages in the present experiment was around $8 \%$, indicating the possibility of the smaller rumen degradability of starch from corn at an advanced maturation stage being compensated by post-ruminal digestion. The apparent decrease in starch digestibility in the silage was not sufficient to induce a decrease in total dietary starch digestibility (Table 4) and in milk yield (Table 3 ). Differences in silage quality may not be reflected in lactation performance when diets are formulated with about $55 \%$ of its dry matter from concentrate feedstuffs (Table 2). Bal et al. (1997) observed that in diets with $33 \%$ of corn silage, plant maturation stage did not affect lactating-cow performance, even though a maturity effect was observed on the digestibility of dietary fiber and starch.

Milk fat content, rumen $\mathrm{pH}$ and chewing time can be utilized to evaluate the effectiveness of dietary fiber (Armentano \& Pereira, 1997). The milk fat content (Table 3) seems to indicate that a change in the profile of dietary carbohydrates from starch to sucrose and from corn silage NDF to finely ground sugarcane NDF, in diets with 200 grams of forage NDF per kg of diet dry matter (Table 2 ), did not change the ruminal fermentation profile. However, the high inclusion of starch from concentrate in all treatments may have obscured possible differences in forage fiber effectiveness.

The physical effectiveness (Armentano \& Pereira, 1997) of finely chopped sugarcane NDF was similar to that of corn silage (Table 5). The chewing time per $\mathrm{kg}$ of dry matter did not increase as corn NDF was replaced with sugarcane NDF (Table 5), contrary to the data of Andrade \& Pereira (1999), who observed longer chewing time per kg of dry matter by heifers fed on diets with $35 \%$ of sugarcane NDF than by heifers fed the same

Table 5 - Chewing activity in minutes per day $\left(\operatorname{min~d}^{-1}\right)$ and minutes per $\mathrm{kg}$ of dry matter intake $\left(\mathrm{min}^{-1}\right)$ and rumen $\mathrm{pH}$ in diets formulated with dent corn silage ensiled at the black layer stage (DC), flint corn silage ensiled at the half milk line stage (FC) or sugarcane (SC).

\begin{tabular}{|c|c|c|c|c|c|c|c|}
\hline & DC & FC & $\mathrm{SC}$ & SEM $^{1}$ & $P$ for forage & $(\mathrm{DC}+\mathrm{FC})$ vs $\mathrm{SC}^{2}$ & $\mathrm{DC}$ vs $\mathrm{FC}^{2}$ \\
\hline & \multicolumn{7}{|c|}{${ }^{-1}{ }^{1}-1-$} \\
\hline Eating time & 236 & 220 & 234 & 10 & 0.52 & 0.64 & 0.31 \\
\hline Rumination time & 469 & 490 & 453 & 24 & 0.57 & 0.39 & 0.54 \\
\hline \multirow[t]{2}{*}{ Chewing time } & 704 & 710 & 687 & 23 & 0.77 & 0.49 & 0.87 \\
\hline & -..- & & -1 & $-\mathrm{mi}$ & 1. & & \\
\hline Eating time & 10.8 & 9.3 & 11.4 & 0.6 & 0.10 & 0.11 & 0.13 \\
\hline Rumination time & 21.3 & 20.7 & 22.2 & 1.3 & 0.72 & 0.46 & 0.77 \\
\hline Chewing time & 32.1 & 30.1 & 33.6 & 1.5 & 0.29 & 0.19 & 0.37 \\
\hline Rumen pH & 6.01 & 6.02 & 6.08 & 0.12 & 0.92 & 0.69 & 0.96 \\
\hline
\end{tabular}

${ }^{1} \mathrm{SEM}=$ Standard error of the mean.

${ }^{2}$ Contrasts: $(\mathrm{DC}+\mathrm{FC})$ versus $\mathrm{SC}$ and $\mathrm{DC}$ versus FC. 
proportion of dietary corn silage NDF. These results did not demonstrate the need for adding long fiber to diets formulated with sugarcane and high content of starch-rich concentrates, comparatively to corn silage. Even though no measurement was made, particle size of the diet containing sugarcane was smaller than for diets containing silage, but it did not result in symptoms of ruminal acidosis such as low and variable intake (Figure 1), low milk fat content, or reductions in chewing activity and rumen pH (Tables 3 and 5) (Barker et al., 1995).

The literature on ruminal fermentation profile of diets containing sugarcane reports $\mathrm{pH}$ values near 7 (Aroeira et al., 1995; Ludovico \& Mattos, 1997; Matarazzo, 1999; Preston \& Leng, 1980), which is higher than the values observed in this work (Table 5). The lower values observed here are probably a consequence of the utilization of lactating animals with high intake of diets rich in fast fermentating carbohydrates. Gallo et al. (2000) also recorded rumen $\mathrm{pH}$ values around 6.2 in sugarcane-fed Holstein heifers. It seems that high rumen $\mathrm{pH}$ is not a trait of animals consuming diets with sugarcane as the only forage; this is probably a consequence of the low dry matter intake in other experiments (Preston \& Leng, 1980; Aroeira et al., 1995; Ludovico \& Mattos, 1997; Matarazzo, 1999).

\section{CONCLUSIONS}

Replacing corn silage by sugarcane in diets with 200 grams of forage NDF per kg of dietary dry matter depressed intake $(6.9 \%)$ and milk yield $(7.3 \%)$ of cows yielding $34 \mathrm{~kg}$ of milk per day. Sugarcane seems to be an option to feed groups of Holstein cows during lactation stages in which nutrient demand is not at a maximum. The performance of dairy cows consuming diets containing dent corn silage ensiled at the physiological maturity stage was similar to the performance of cows fed diets with flint corn ensiled earlier.

\section{REFERENCES}

ALLEN, M.S. Effects of diet on short-term regulation of feed intake by lactating cattle. Journal of Dairy Science, v.83, p.1598-1624, 2000.

ANDRADE, M.A.F; PEREIRA, M.N. Performance of Holstein heifers on fresh sugarcane as the only dietary forage. Journal of Dairy Science, v.82, p.91, 1999. Supplement 1 .

ARMENTANO, L.E.; PEREIRA, M.N. Measuring the effectiveness of fiber by animal response trials. Journal of Dairy Science, v.80, p.1416-1425, 1997.

AROEIRA, L.J.M.; LOPES, F.C.F.; DAYRELL, M.S.; LIZIEIRE, R.,S.; TORRES, M.P. Digestibilidade, degradabilidade e taxa de passagem da cana-de-açúcar mais uréia e do farelo de algodão em vacas mestiças Holandês x Zebu em lactação. Revista da Sociedade Brasileira de Zootecnia, v.24, p.1016-1026, 1995.

ASSOCIATION OF OFFICIAL AGRICULTURAL CHEMISTS Official methods of analysis. 12.ed. Washington: AOAC, 1975. 1094p.

BAL., M.A.; COORS, J.G.; SHAVER, R.D. Impact of the maturity of corn for use as silage in the diets of dairy cows on intake, digestion, and milk production. Journal of Dairy Science, v.80, p.2497-2503, 1997.
BAL., M.A.; SHAVER, R.D.; JIROVEC, A.G.; SHINNERS, K.J.; COORS, J.G. Crop processing and chop length of corn silage: Effects on intake, digestion, and milk production by dairy cows. Journal of Dairy Science, v.83, p.1264-1273, 2000.

BARKER, I.K.; VAN DREUMEL, A.A.; PALMER, N. The alimentary system. In: JUBB, K.V.F.; KENNEDY, P.C.; PALMER, N. Pathology of domestic animals. San Diego: Academic Press, 1995. p.273-291.

CALESTINE, G.A.; PEREIRA, M.N.; BRUNO, R.G.S.; VON PINHO, R.G.; CORREA, C.E.S. Effect of corn grain texture and maturity on ruminal in situ degradation. Journal of Dairy Science, v.84, p.419, 2001. Supplement 1.

CLARK, P.W.; ARMENTANO, L.E. Influence of particle size on the effectiveness of the fiber in corn silage. Journal of Dairy Science, v.82, p.581-588, 1999.

COORS, J.G.; CARTER, P.R.; HUNTER, R.B. Corn silage. In: HALLAVER, A.R. Specialty corns. CRC PRESS, 1994. p.305-340.

CORRÊA, C.E.S.; SHAVER, R.D.; PEREIRA, M.N.; LAUER, J.G.; KOHN, K. Relationship between corn vitreousness and ruminal in situ starch degradability. Journal of Dairy Science, v.85, p.3008-3012, 2002.

FONSECA, A.H; VON PINHO, R.G.; PEREIRA, M.N.; BRUNO, R.G.S.; CARVALHO, G.S. Características agronômicas, químicas e nutricionais de híbridos de milho, visando à produção de silagem de alto valor nutritivo. Revista Ceres, v.49, p.41-54, 2002.

FORNASIERI FILHO, D. A cultura do milho. Jaboticabal: FUNEP, 1992 273p.

GALLO, P.C.S.; PEREIRA, M.N.; ANDRADE, M.A.F. Effect of dietary sugarcane concentration on heifer growth. Journal of Dairy Science, v.83, p.114, 2000. Supplement 1.

GARRET, E.F.; PEREIRA, M.N.; NORDLUND, K.V.; ARMENTANO, L.E.; GOODGER, W.J.; OETZEL, G.R. Diagnostic methods for the detection of subacute ruminal acidosis in dairy cows. Journal of Dairy Science, v.82, p.1170-1178, 1999

GUIMARÃES, V.D. Fatores que controlam a dureza do grão de milho Viçosa: UFV, 1997. 67p. (Dissertação - Mestrado)

HUBER, J.T.; KUNG JR., L. Protein and nonprotein utilization in dairy cattle. Journal of Dairy Science, v.64, p.1170-1195, 1981.

LUDOVICO, A.; MATTOS, W.R.S. Avaliação de dietas a base de cana-deaçúcar e diferentes níveis de sementes de algodão. Revista da Sociedade Brasileira de Zootecnia, v.26, p. 403-410, 1997.

MATARAZZO, S.V. Teores de uréia com cana-de-açúcar: Fermentação ruminal e concentrações de uréia plasmática em bovinos leiteiros. Piracicaba: USP/ESALQ, 1999. 63p. (Dissertação - Mestrado)

MENDONÇA, S.S.; CAMPOS, J.M.S.; VALADARES FILHO, S.C.; VALADARES, R.F.D.; LANA, R.P.; SOARES, C.A.; ASSIS, A.J. Canade-açúcar como forrageira única para vacas de leite: 1. Produção e composição do leite. In: REUNIÃO ANUAL DA SOCIEDADE BRASILEIRA DE ZOOTECNIA, 38., Piracicaba, 2001. Anais. Piracicaba: SBZ, 2001. p.1212-1214.

NATIONAL RESEARCH COUNCIL. Nutrient requirements of dairy cattle. 7.ed. Washington: National Academy of Sciences, 2001. 381p.

OBA, M.; ALLEN, M.S. Effects of brown midrib 3 mutation in corn silage on dry matter intake and productivity of high yielding dairy cows. Journal of Dairy Science, v.82, p.135-142, 1999.

PEREIRA, M.N.; GARRET, E.F.; OETZEL, G.R.; ARMENTANO, L.E. Partial replacement of forage with nonforage fiber sources in lactating cow diets. I. Performance and health. Journal of Dairy Science, v.82, p.2716-2730, 1999.

PHILIPPEAU, C.; LE DESCHAULT DE MONREDON, F.; MICHALETDOREAU, B. Relationship between ruminal starch degradation and the physical characteristics of corn grain. Journal of Animal Science, v.77, p.238-243, 1999.

PHILIPPEAU, C.; MICHALET-DOREAU, B. Influence of genotype and stage of maturity of maize on rate of ruminal starch degradation. Animal Feed Science and Technology, v.68, p.25-35, 1997.

PRESTON, T.R.; LENG, R.A. Utilization of tropical feeds by ruminants. In: RUCKEBUSCH, Y.; THIVEND, P. Digestive physiology and metabolism in ruminants. Connecticut: AVI Publishing, 1980. p.621-640.

RIBEIRO, E.G.; ESTRADA, L.H.C.; FONTES, C.A.A.; AGUIAR, R.S.; ROCHA, L.V. Níveis de substituição da silagem de milho pela cana-deaçúcar na alimentação de vacas de leite (consumo alimentar). In: REUNIÃO ANUAL DA SOCIEDADE BRASILEIRA DE ZOOTECNIA, 37., Viçosa, 2000. Anais. Viçosa: SBZ, 2000. p.464. 
SAS. User's Guide: Statistics, version 5 Edition. Cary: Statistical Analysis System Institute, 1985.

STACCHINI, P.F. Efeito dos teores de uréia e do farelo de soja sobre a digestibilidade e balanço de nitrogênio em vacas leiteiras alimentadas com cana-de-açúcar. Piracicaba: USP/ESALQ, 1998. 67p. (Dissertação - Mestrado)

SUCUPIRA, M.C.A. Efeito de níveis crescentes de uréia no consumo, volume ruminal e taxa de passagem em vacas Holandesas alimentadas com cana-de-açúcar-de-açúcar. Piracicaba: USP/ESALQ, 1998. 66p. (Dissertação - Mestrado)
VAN SOEST, P.J.; ROBERTSON, J.B.; LEWIS, B.A. Methods for dietary fiber, neutral detergent fiber, and nonstarch polysaccharides in relation to animal nutrition. Journal of Dairy Science,v.74, p.3583-3597, 1991. WILLIAMS, C.H.; DAVID, D.J.; IISMAA, O. The determination of chromic oxide in feces samples by atomic absorption spectrophotometry. Journal of Agricultural Science, v.59, p.381-385, 1962.

Received January 14,2002

Accepted July 12, 2003 